\title{
Exploring the Power Conditioning System for Fuel Cell
}

\author{
Cheng K.W.E., Sutanto D, Ho Y.L. and Law K.K. \\ Power Electronics Research Centre \\ Department of Electrical Engineering \\ The Hong Kong Polytechnic University \\ Hung Hom, Hong Kong
}

\begin{abstract}
This paper presents an analysis of various fuel cells and their characteristics. A range of power conditioning systems including the inverter and $\mathrm{DC} / \mathrm{DC}$ converter for the fuel cell is then proposed. Experimental result is used to support the analysis.
\end{abstract}

\section{INTRODUCTION}

The environment concern is now the driving force for alternative energy. Also, deregulation, power quality, byproduct and grid congestion are also the secondary needs for more efficient use of fuel in power generation. The fuel cell is a chemical device, which produces electricity directly without any intermediate stage. The emission is made up of only favourable gases and water. The noise emission is low. It has recently received attention because of its zero emission of green house gases and high power density. The power density of a typical fuel cell is $200 \mathrm{Wh} / 1$ which is nearly ten times of a battery. Therefore it can be used in electric vehicle or home emergency power source [1- 3] and power utility of $500 \mathrm{~kW}$ [4]. In many countries such as in Malaysia or China, town effluent wastes, and even agricultural wastes, which are plentiful, have not been used anywhere, despite serious energy shortage. In certain areas, the electric power source is simply not available or inconsistent.

The core of the Fuel Cell consists of two electrodes, the anode and the cathode, separated by a membrane electrolyte. For certain fuel cells, the electrodes are coated on one side with a thin layer of platinum as a catalyst. At the anode, fuel decomposes into free electrons and protons (positive hydrogen ions) and/or other gas ions (charge carriers). The free electrons are conducted in the form of usable electric current through the external electrical circuit. The charge carriers (such as protons in Hydrogen fuel cell) migrate through the membrane electrolyte to the cathode where they combine with oxidant or oxygen from gas/air input and electrons circulate from the external circuit to form depleted oxidant or pure water and heat. Individual fuel cells are combined or connected in cascade to provide the amount of electrical power required.

The DC generated can be converted to $\mathrm{AC}$ through inverter technology or transformed into other DC voltage using DC/DC converters or a combination of two. The power converters used in High voltage DC (HVDC) power transmission was linecommutated or forced commutated. With the development of GTO and IGBT, the power converters can be switched more efficiently and less costly [5] and the relative difficulty of interrupting DC current is not a problem. The research in stepdown or step-up converters has been reported in various voltages [6]. The conversion of HVDC to a lower DC voltage or an $\mathrm{AC}$ voltage for home or industrial use has not been studied thoroughly in the past. Most of the research publications have concentrated on the investigation of HVDC for use in extra high voltage (EHV) transmission [7-8] and very few publications have been published on the application od DC distribution for low voltage application [9]. This paper compares various fuel cell technology and proposed a range of solution for their power conditioning.

\section{FUEL CELL}

There exist various fuel cells available for industrial use. Although not all of them are available commercially, it is believed that in a few years time more will become available in the market. There are 5 popular fuel cells currently being investigated for use in industry:

- Proton Exchange Membrane

- Solid Oxide

- Molten Carbonate

- Phosphoric Acid

- Aqueous Alkaline

A. Proton Exchange

It is one of the most classical fuel cell. It is actually based on the reverse chemical reaction of electrolysis of water and free electron is generated. The proton (positive hydrogen ion) conducting membrane is placed between two electrodes. This membrane is made of Teflon-based material. Some lower class membranes may just use polystyrene. The main advantage is that the operating temperature is very low, around $85^{\circ} \mathrm{C}$. In order to optimize the efficiency, high-pressurized gas is used. The chemical of the anode and cathode reactions can be described respectively as: 
$H_{2} \rightarrow 2 H^{+}+2 e^{-}$

$\frac{1}{2} \mathrm{O}_{2}+2 \mathrm{H}^{+}+2 e^{-}->\mathrm{H}_{2} \mathrm{O}$

Because of the long history of this type of cell fuel, there are currently numerous manufacturers for this product, such as: $\mathrm{H}-$ Power Ltd, Plug Power, Siemens, Ballard and Analytic Power. Some of them are available in small test-kits for educational and commercial use. The efficiency is quite low, around $35 \%$. The by-product is very favourable: only water. Also because of the low temperature operation, this fuel cell has been used in small power commercial and consumer products such as supply for laptop computer, bicycle, electric vehicle and even mobile phone.

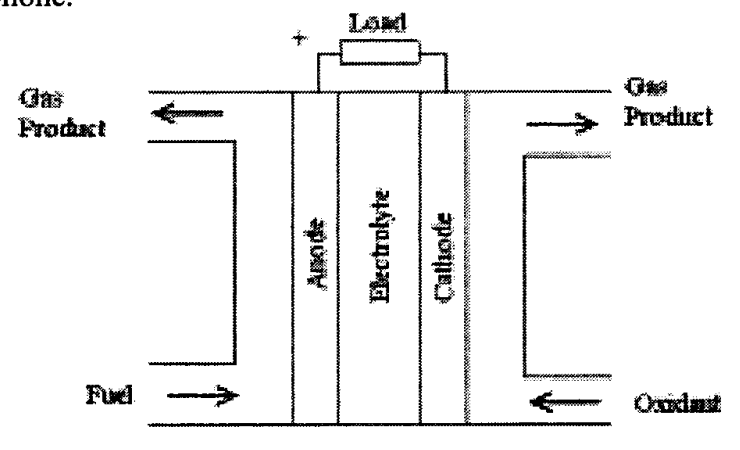

Fig. 1 Structure of Fuel Cell

B. Solid Oxide

Solid Oxide fuel cell is operated at high temperature, typically around $1000^{\circ} \mathrm{C}$. The electrolyte required is ytria-stablilized zirconia. Because of its high temperature operation, the cell can also supply heating for co-generation operation with gas turbines, steam turbines. Because of the high temperature operation, natural gas and coal gas can be used for the fuel such that $\mathrm{Co}$ and $\mathrm{H}_{2}$ can be reformed. The chemical reaction can be described as:

$\mathrm{H}_{2}+\mathrm{O}^{2-}->\mathrm{H}_{2} \mathrm{O}+2 e^{-}$

$\mathrm{CO}+\mathrm{O}^{2-}-\mathrm{CO}_{2}+2 e^{-}$

$\mathrm{CH}_{4}+4 \mathrm{O}^{2-}->2 \mathrm{H}_{2} \mathrm{O}+\mathrm{CO}_{2}+8 e^{-}$

$\frac{1}{2} \mathrm{O}_{2}+2 e^{-}->\mathrm{O}^{2-}$

The conversion efficiency is about $50 \%$. Today, lower temperature of around $750^{\circ} \mathrm{C}$ is also possible.

\section{Molten Carbonate}

The electrolyte is a molten alkali carbonate mixture with Lithium and potassium salt. The operating temperature is moderate, around $700^{\circ} \mathrm{C}$. As a result, the waste heat can also be used as co-generation and internal reforming. Therefore many fuels are possible such as natural gas, propane and landfill. No catalyst is needed. Their average efficiency is around $50 \%$. The chemical reaction can be described as:

$\mathrm{H}_{2}+\mathrm{CO}_{3}{ }^{2-}->\mathrm{H}_{2} \mathrm{O}+\mathrm{CO}_{2}+2 e^{-}$

$\mathrm{CO}+\mathrm{CO}_{3}^{2-}-\mathrm{CO}_{2}+2 e^{-}$

$\frac{1}{2} \mathrm{O}_{2}+\mathrm{CO}_{2}+2 e^{-}->\mathrm{CO}_{3}{ }^{2-}$

Today, manufacturers including $\mathrm{M}-\mathrm{C}$ power, Mitsubishi produce this type of fuel cell. Then efficiency is $50 \%$.

\section{D. .Phosphoric Acid}

Phosphoric acid electrolyte $\left(\mathrm{H}_{3} \mathrm{PO}_{4}\right)$ is used. The operating temperature is around $200^{\circ} \mathrm{C}$. This type of fuel cell has been developed for a long time and is also commercially available. Manufacturers such as Toshiba, Fuji, Onsi and Mitsubishi have products too. The chemical reaction of the anode and cathode can be given as:

$$
\begin{aligned}
& \mathrm{H}_{2}->2 \mathrm{H}^{+}+2 e^{-} \\
& \frac{1}{2} \mathrm{O}_{2}+2 \mathrm{H}^{+}+2 e^{-}-\mathrm{H}_{2} \mathrm{O}
\end{aligned}
$$

The conversion efficiency is around $40 \%$. The required gases can be natural gas, LPG, methanol and hydrogen.

\section{E. Aqueous Alkaline}

This is also one of the favourable types because of the low operating temperature, around $80^{\circ} \mathrm{C}$. The fuel is pure hydrogen gas therefore there exists purity requirement. The conversion efficiency is very high, typically around $60 \%$. Because of this, it is now being used in Space program. The chemical reaction is:

$$
\begin{aligned}
& \mathrm{H}_{2}+2 \mathrm{OH}^{-}->2 \mathrm{H}_{2} \mathrm{O}+2 e^{-} \\
& \frac{1}{2} \mathrm{O}_{2}+\mathrm{H}_{2} \mathrm{O}+2 e^{-}->2 \mathrm{OH}^{-}
\end{aligned}
$$

The main manufacturers are: Energy Ventures, Gaskatel Gmbh, International Fuel Cell and Zenvco Ltd.

\section{ANALYSIS OF FUEL CELL}

A. Efficiency 
From the above analysis, it can be seen that the efficiency of the fuel cell is quite high. Table 1 compares various type of power generation. It can be seen that Fuel Cell gives a good promise for the future fuel energy supply.

Table 1

Comparison of efficiency of power generation

\begin{tabular}{|l|l|l|l|}
\hline & Electricity & Co-generation & Total \\
\hline Fuel Cell & $40-60 \%$ & $20-30 \%$ & $60-80 \%$ \\
\hline Diesel Engine & $30-40 \%$ & $0 \%$ & $30-40 \%$ \\
\hline Gas Turbine & $25-35 \%$ & $0 \%$ & $25-35 \%$ \\
\hline Gas Engine & $25-35 \%$ & $0 \%$ & $25-35 \%$ \\
\hline
\end{tabular}

\section{B. Cogeneration}

The waste heat generated by the fuel cell is usually used for cogeneration such as steam, air-conditioning, hot air and heating. The overall efficiency of such a system can be as high as $80 \%$. The waste heat can also be used as internal reformer to convert fuel gas into necessary components.

\section{Electrical characteristics}

The fuel cell voltage is usually very small, theoretical maximum is around $1.2 \mathrm{~V}$. A typical cell electrical voltage against current density is shown in Fig 2. It can be seen that there exists a linear region where the voltage drop linearly with the current density. This is because the Ohmic contact which limits the output voltage. Beyond this region, the change in output voltage varies rapidly. At very high current density, the voltage drops significantly because of the gas exchange efficiency. At low current level, the Ohmic loss becomes less significant, the increase in output voltage is mainly due to the activity of the chemicals.

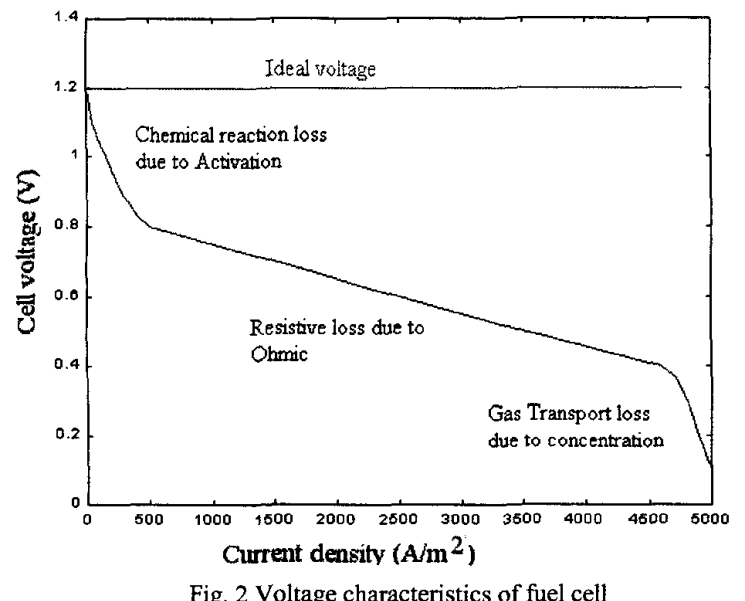

IV POWER CONDITIONING CIRCUIT

\section{A. General configuration}

A typical fuel cell plant is shown in Fig. 3. It can be observed that it consists of the primary electricity electric energy supply, and the secondary, co-generation use, utilizing the waste heat for heating, etc. The electricity output is used to supply normal load demand or where there is excess capacity it can be sold back to the grid.

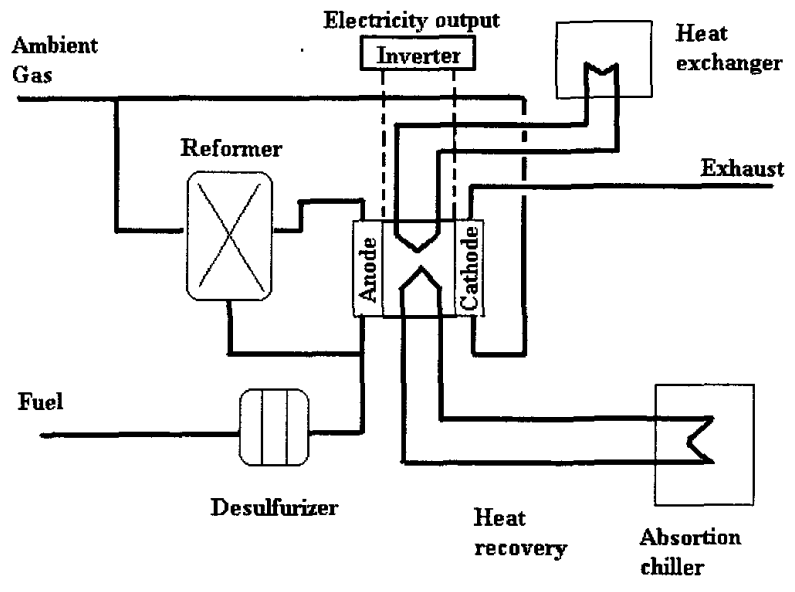

Fig. 3 A schematic diagram of fuel cell system

B. The electrical system

The electrical system of the fuel cell can be shown in Fig 4 . It can be seen that the DC output from the fuel cell is inverted to an $\mathrm{AC}$ voltage using an inverter and $\mathrm{DC}$ voltage generated through DC/DC converter. The main concern is the design of the power conditioning system for this DC output from the fuel cell.

\section{Power Conditioning system}

The power conditioning circuits for the fuel cell are inverters and $\mathrm{DC} / \mathrm{DC}$ converters. In general inverters can be classified as the hard switching inverters and soft-switching inverters. The $\mathrm{DC} / \mathrm{DC}$ converter also has many topologies for selection. This includes the hard-switching and soft-switching types.

\section{INVERTER CONDITIONING SYSTEM}

Fig 4 to 7 shows four popular inverter topologies for this fuel cell application. They are:

(i) Hard-switching inverter (CHSI)- the most classical type but it suffers from switching loss. The design is well proven and many industrial drives are adapted to this topology. 
(ii) Resonant phase leg inverter (RPLI) - it is an improvement to the hard-switching inverter. Its modulation scheme can also be regulate-sampling and zero-voltage switching can be achieved to transistors. A modified version by improving the modulation method, variable frequency modulation [11] can further improve the soft-switching range.

(iii) Auxilliary resonant commutated pole inverter (ARCPI) - it is the improvement to the previous topology because it uses auxiliary transistors to assist the zero-voltage switching of the main devices where the zero-voltage switching cannot be achieved during light load. The advantage is of course of wide range of load, but the component count is high.

(iv) Active clamp resonant DC link inverter (ACRDI)- It is an improvement to the classical resonant DC link inverter where the DC link voltage will go to double as the original DC link voltage. After using additional clamping devices, the DC link voltage can be controlled to 1.3 times of the input voltage. However, the circuit cannot use the regular-sampling modulation and only delta modulation can be used. Therefore it does have certain restriction. In many experimental results show that, the zero-voltage switching of the DC link resonant switching is not very reliable. Therefore, today, very few industrial drives adapt this topology.

Table 2 shows a comparison of these four inverters for use in Fuel cell power conditioning system. It can be seen that the RPLI and ARCPI show the most favourable operation when compared with the others.

Table 2

Comparison of different inverter topologies

\begin{tabular}{|c|c|c|c|c|}
\hline & CHSI & RPLI & ARCPI & ACRDI \\
\hline Soft-switching & Poor & Fair & Good & Good \\
\hline Efficiency & $\begin{array}{l}\text { Quite } \\
\text { good }\end{array}$ & Good & Good & Good \\
\hline Device Stress & Good & Fair & Good & Quite \\
\hline Radiative EMI & Poor & $\begin{array}{l}\text { Quite } \\
\text { good }\end{array}$ & Good & Good \\
\hline Conductive EMI & $\begin{array}{l}\text { Quite } \\
\text { good }\end{array}$ & $\begin{array}{l}\text { Quite } \\
\text { good }\end{array}$ & Good & $\begin{array}{l}\text { Quite } \\
\text { good }\end{array}$ \\
\hline Component count & Low & Low & High & Medium \\
\hline Cost & Low & Low & Higher & Higher \\
\hline Passive components & Easy & Difficult & Fair & Difficult \\
\hline Control sensitivity & Stable & Stable & $\begin{array}{l}\text { Sensitiv } \\
\mathrm{e}\end{array}$ & $\begin{array}{l}\text { Sensitiv } \\
\text { e }\end{array}$ \\
\hline Output quality & Good & Fair & Good & $\begin{array}{l}\text { Quite } \\
\text { good }\end{array}$ \\
\hline $\begin{array}{l}\text { Application to fuel } \\
\text { cell power } \\
\text { conditioning }\end{array}$ & $\begin{array}{l}\text { Low } \\
\text { power } \\
\text { fuel cell }\end{array}$ & $\begin{array}{l}\text { Not very } \\
\text { high } \\
\text { freq }\end{array}$ & $\begin{array}{l}\text { Medium } \\
\text { to high } \\
\text { power }\end{array}$ & $\begin{array}{l}\text { Not } \\
\text { suitable }\end{array}$ \\
\hline
\end{tabular}




\section{DC/DC CONVERTER CONDITIONING SYSTEM}

The classical DC/DC converter such as H-bridge type forward converter as shown in Fig 8 are popular topology. This converter is well developed and very stable. However, in order to improve the switching loss, a soft-switching type of the converter is necessary. Fig 9 shows a H-bridge series resonant converter. This converter is also very matured. The main advantage is its inherited short-circuit protection and there is no saturation problem of the transformer whereas the hardswitching forward converter requires very accurate bi-polar waveform or current mode control to the transformer otherwise the transformer will experience saturation and causes extra loss and dangerous operation.

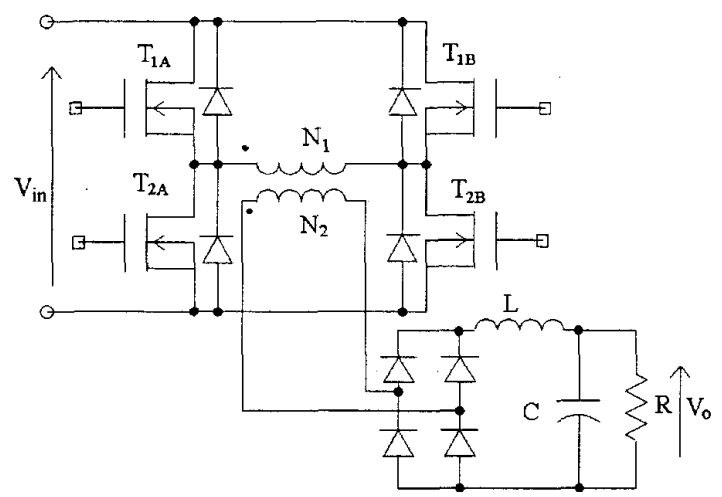

Fig $8 \mathrm{H}$-bridge forward converter

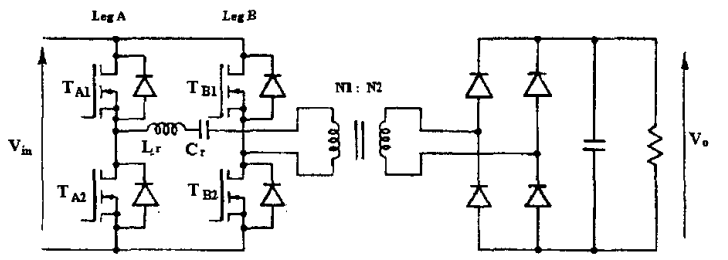

Fig 9. Series-resonant converter

The DC/DC converter can also be used as the DC isolation for the inverter. This is because to insert a low frequency transformer at the output of the inverter is very bulky and therefore a DC/DC converter is usually put between the fuel cell and the inverter. This acts as two purposes: One is the DC isolation and the second is to produce sufficient voltage for the inverter input. For example, only $200 \mathrm{~V}$ fuel cell stack cannot produce $380 \mathrm{~V}$ line voltage. A step up dc converter is needed.

\section{EXPERIMENTAL RESULTS}

The experimental of the RPLI is shown in Fig 10. The adaptation of this inverter because of its low component count and easier for implementation. The experimental results for $4 \mathrm{~kW}$ is shown. The measured efficiency is $93 \%$.

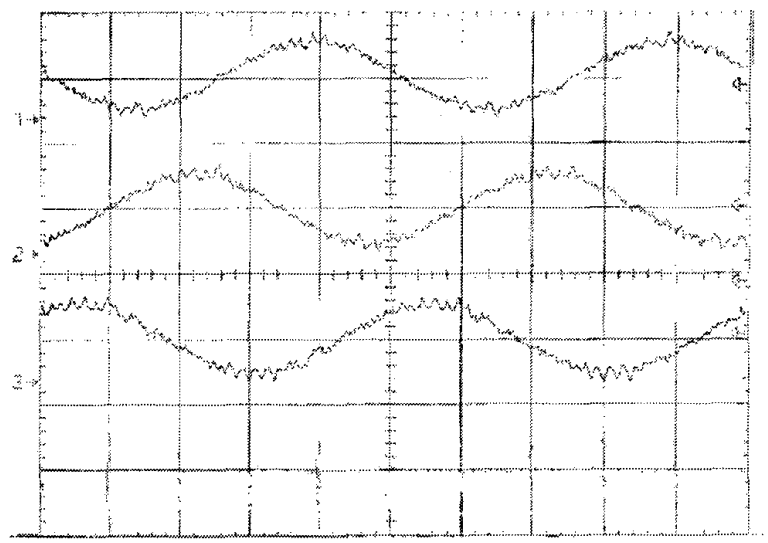

Fig. 10 Experimental result of the RPLI Voltages of three phases: $400 \mathrm{~V} / \mathrm{div}$

\section{B. DC/DC converter}

Preliminary results on the performance of the series resonant converter operated at $\mathrm{Vin}=180 \mathrm{~V}, \mathrm{Vo}=550 \mathrm{~V} 50 \mathrm{kHz}$ is shown in Fig 11. The output power is $2.2 \mathrm{~kW}$. Zero-voltage switching can be observed. The efficiency is $91 \%$.

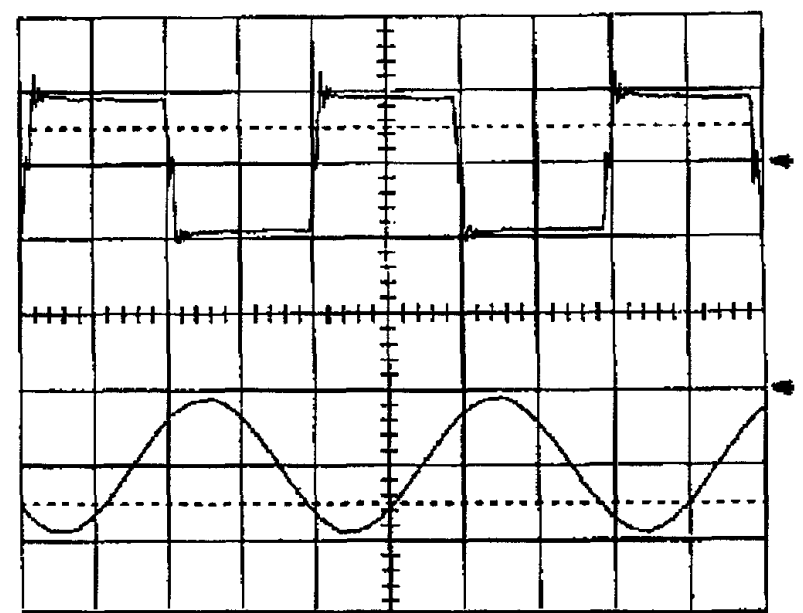

Fig 11a. Experimental waveforms of the resonant converter Transformer primary voltage $(200 \mathrm{~V} / \mathrm{div})$; $\mathrm{Vcr}: 1 \mathrm{kV} / \mathrm{div}$ 


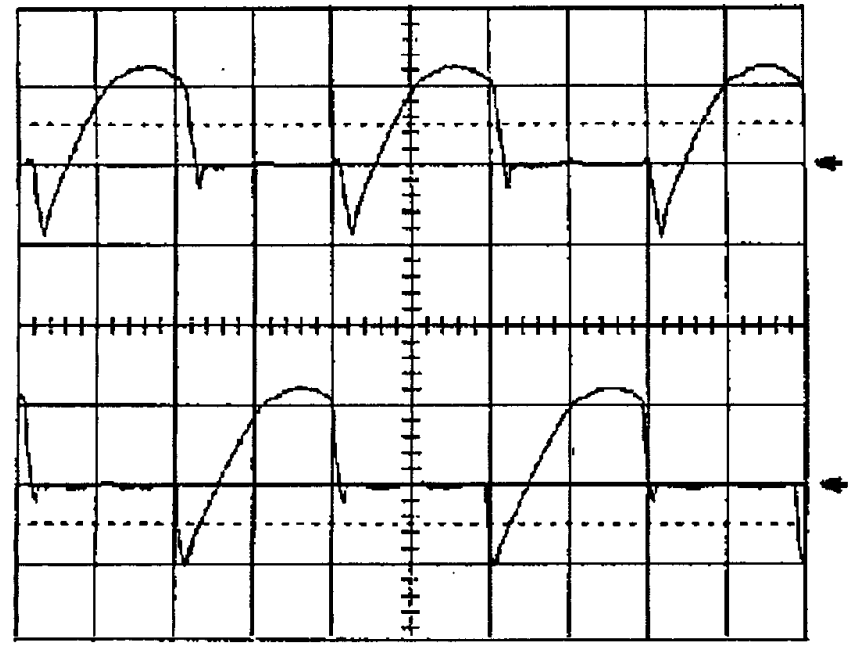

Fig 11b. Experiment waveforms of the DC/DC converter Top: current of $\mathrm{T}_{\mathrm{A} 1}(20 \mathrm{~A} / \mathrm{div})$; bottom: current of $\mathrm{T}_{\mathrm{B} 1}$ (20A/div)

\section{CONCLUSION}

An analysis of the fuel cell for use in the power conditioning system is presented. It is believed that Aqueous Alkaline type will has a promised result. The electric power conditioning requires a $\mathrm{DC} / \mathrm{DC}$ converter for isolation and voltage step-up and an inverter is needed for $\mathrm{AC}$ output. Various inverter and DC/DC converter topologies have been presented. Currently, the fuel cell is still expensive and it will take several years for it to be commonly available.

\section{ACKNOWLEDGEMENT}

The authors gratefully acknowledge the financial support of Research Committee of The Hong Kong Polytechnic University

\section{REFERENCES}

[1] A.T-Raissi, A.Banerjee, and K.G.Sheinkopf, -Current technology of fuel cell systems7', Energy Conversion Engineering Conference, Vol. 3, 1997, pp 1953-1957.

[2] J.H.Hirschenhofer, " 1996 fuel cel I status", Energy Conversion Engineering Conf., Vol. 2, 1996, pp 1084-1089.

[3] R.R.Wimmer, "Fuel cell transit bus testing \& development at Georgetown university", Energy Conversion Engineering Conference, Vol. 2, 1997, pp 825-830.

[4] G.A.O'Sullivan, Fuel cell inverters for utility applications", PESC 2000, Vol. 3, pp. 1191-1194.

[5] P.Lamell and A.Ekstrom, "HVDC tapping station: Power tapping from a DC transmission line to a local AC network", EPE 1991, Vol 1, pp 252257.

[6] N.Kimura, M.Kishimoto and K.Matsu-ra, "Dynamic behaviour of HVDC system using forced commutation converter in AV system fault", EPE 1991, Vol. 1, pp 225-230.

[7] A.Routray, P.k.Dash and S.K.Panda, "A Fussy self-tuning PI controller for HVDC links", IEEE Transactions on Power Electronics, Vol 11, No. 5, Sep 1996, pp 669-679

[8] T.Hasegawa, K.Yamaji, H.Irokawa and S.Tanabe, "A 500-KV Value using 8-KV LTT', IEE AC and DC Power Transmission Conference, Apr 1996, pp 393-397.

[9] R.Hill, "DC-DC Converters for distribution power architectures", PCIM Europe, No.1, 1998,pp32-33.

[10] K.H.Liu,, R.Oruganti and F.C.Lee, "Resonant switches-topologies and characteristics, IEEE Power Electronics Specialists Conference, 1985, pp 106-116.

[11] K.W.E.Cheng, "Zero-voltage switching modulation technique for resonant pole inverter", IEE Electronics Letters, Vol 35, No. 9, April 1999, pp. 692693.

[12] D.M.De Doncker and J.P.Lyons, "The auxiliary resonant commutated pole inverter", IEEE-IAS Conf. 1990, pp. 